\title{
Oral Dysplasia
}

National Cancer Institute

\section{Source}

National Cancer Institute. Oral Dysplasia. NCI Thesaurus. Code C129863.

A morphologic finding of dysplastic epithelial cells in the oral cavity. 